\title{
URBAN/COMMUNITY FORESTRY IN THE INTERMOUNTAIN WEST
}

\author{
by Michael R. Kuhns
}

\begin{abstract}
This paper summarizes the people/population factors, site factors, and program factors influencing urban and community forestry (U\&CF) in the Intermountain West, including information gathered through a limited survey of U\&CF experts in the region. The major factors that emerged include a relatively low population living in cities and towns scattered over a large area, major population growth now and in the future, lack of native trees in the valleys where most people live, harsh conditions for growing trees, poorly funded and staffed U\&CF programs, and lack of community and citizen awareness and knowledge, particularly regarding tree selection and landscape design and care. An improving future is predicted for U\&CF in the region, based on population growth and demographic change, increasing citizen interest and awareness, enhanced funding and staffing of U\&CF programs, and the availability of better-trained arborists.
\end{abstract}

Keywords. Urban forestry; community forestry; Intermountain West; population; demographics; site; programs.

\section{The Intermountain West-Trees, People, and Water}

Various urban and community forestry-related subjects have been researched over the years, but little formal study has been done on urban and community forestry characteristics, limitations, and programs within the Intermountain West. This paper reports results of a study of urban and community forestry in the Intermountain West region of the United States. It included gathering physical data on climate, elevation, and topography, and gathering social/cultural and program data and information through a survey of urban forestry professionals and others in the region and from U.S. Census Bureau sources.

\section{Methods}

The "Intermountain West" as referred to here (shaded area in Figure 1) extends from Canada to Mexico and includes all of the states of Idaho, Nevada, Utah, and Arizona, as well as eastern Washington and Oregon, extreme eastern Cali- fornia (to the eastern flank of the Sierra Nevada range), and the western portions of Montana, Wyoming, Colorado, and New Mexico. Physiographic provinces included in this region are nearly all of the Colorado Plateau and Basin and Range, and portions of the Rocky Mountains, Columbia Plateau, and Interior Mountains and Plateaus.

Climate, physical, population, and other cultural data on this region were gathered from U.S. Census Bureau Web sites (US Census Bureau 1997a, 1997b) and from the "Statistical Abstract of the United States 1994" Web site of MedAccess Corporation (MedAccess 1997), consisting of a compilation of data from a number of government sources. Soil $\mathrm{pH}$ and salinity information was obtained from Utah State University's Soil Testing Lab.

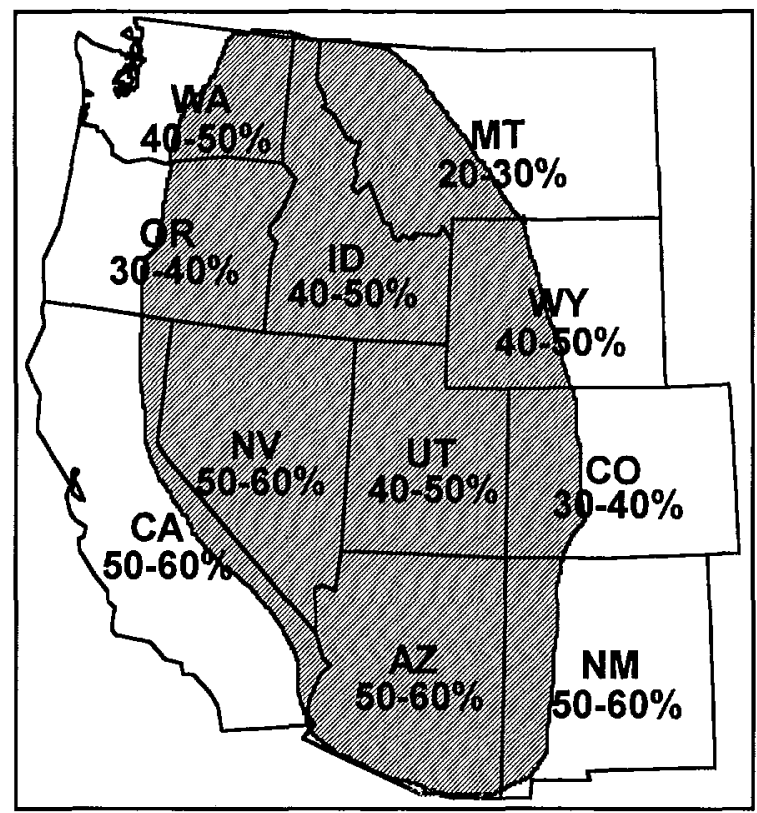

Figure 1. Projected population growth in Intermountain West states from 1995 to 2025. 
Information on urban and community forestry (U\&CF) programs, people problems, site problems, and common trees was gathered by use of a mail survey. A 2-page questionnaire was faxed and mailed to 27 people throughout the region on July 7,1997 . The surveyed group consisted of persons chosen for their in-depth knowledge of U\&CF programs in the region, including state urban forestry coordinators, state urban forestry volunteer coordinators, Extension educators involved in U\&CF, utility arborists, and USDA Forest Service State and Private Forestry personnel. $A$ high return rate was needed in a short time, so questionnaires were mailed and faxed, and individuals were called to prompt their participation. Mailed surveys included a signed request for participation along with an explanation of the survey purpose and instructions for its completion. This resulted in the return of 21 completed questionnaires for a $78 \%$ response rate.

The questionnaire consisted of 10 questions including respondents' ratings of the overall strength or quality of U\&CF in their areas, its specific strengths and weaknesses, their feelings about the future of U\&CF and why it might get better or worse in the next 5 to 10 years, differences between U\&CF in this region and elsewhere, U\&CF research needs, their area's people-, tree-, and site-related problems, and the most abundant tree species. They also provided their name, title, and a description of the geographic area they covered.

\section{Results and Discussion: Factors Affecting U\&CF in the Intermountain West}

People/population factors. Population distribution and demographics likely have significant influences on U\&CF in the Intermountain West. The region's population is low, with 11.7 million people, or $4.4 \%$ of U.S. population, scattered over parts of 11 large states as of 1995. Overall population density is very low, with 14 people per square mile in Nevada and Idaho, 23 in Utah, and 37 in Idaho as of 1995 , compared with 74 people per square mile for the entire United States. Arizona has the largest proportion of the region's population at $36 \%$.
The region's population is low but growing, increasing $16 \%$ between 1990 and 1995 and $41 \%$ between 1980 and 1995. Six of the 7 fastest-growing states in the United States are located partially or completely in the region, with Arizona and Nevada predicted to grow $50 \%$ to $60 \%$ by 2025 and Utah and Idaho $40 \%$ to $50 \%$ (Figure 1). Most of this increase is occurring in cities, with the proportion of urban population at $88 \%$ in Nevada in $1990,87 \%$ in Arizona and Utah, and $57 \%$ in Idaho, compared to $75 \%$ urban population for the entire United States.

Disposable income per person varies widely in the region, with Nevada ranked 9th out of 50 states, while Idaho is ranked 36th, Arizona 37th, and Utah 49th. In Utah this may partly be due to large family size, with Utah's mean household size of 3.08 considerably larger than the national mean of 2.62 (US Census Bureau 1997a). Low per-person disposable income indicates a potential lack of available income at both personal and community levels for amenities such landscaping, community trees, and tree care.

Concentration and growth of population in the Intermountain West is leading to compact cities and towns with inadequate greenspace and urban trees. Cities and towns throughout the region are growing so quickly that open space and existing trees are quickly eliminated. Sentiment for planning and restrictions on growth is increasing, but planned growth often comes too late to save adequate greenspace. Urban greenspace and community forests often are developed as an afterthought.

Site factors. Climate, topography, and geology also likely have strong influences on U\&CF in the Intermountain West, with the overriding climatic factor being lack of water at low elevations where people live. Annual precipitation ranges from $41 \mathrm{~cm}$ (16 in) in Salt Lake City and Spokane, to $30 \mathrm{~cm}$ (12 in) in Boise, to $19 \mathrm{~cm}$ (7.5 in) in Reno and Phoenix. July relative humidities average $18 \%$ in Reno; $20 \%$ to $22 \%$ in Phoenix, Salt Lake City, and Boise; and $27 \%$ in Spokane. These extremely dry conditions limit urban populations to areas where snow-melt-fed rivers or streams exit mountain ranges at the mouths of canyons. Though population has been low enough that 
water use was fairly unrestricted, restrictions are becoming more common as population increases.

Overall elevation of the region is high, with a mean elevation of $1,859 \mathrm{~m}(6,100 \mathrm{ft})$ in Utah, $1,676 \mathrm{~m}(5,500 \mathrm{ft})$ in Nevada, $1,524 \mathrm{~m}(5,000 \mathrm{ft})$ in Idaho, and $1,250 \mathrm{~m}(4,100 \mathrm{ft})$ in Arizona, contributing to cold winters in most of the region. Summer temperatures in the lower valleys can be high, however, especially in southern portions of the region, with temperatures over $38^{\circ} \mathrm{C}$ $\left(100^{\circ} \mathrm{F}\right)$ common. Winds also can be severe in winter or summer, especially when channeled due to the placement of cities in relation to mountain ranges.

Soil conditions at low elevations are quite limiting to most trees, with soil pH usually above 7 , and $\mathrm{pH}$ 's of 7.8 to 8.4 common. No native trees exist on most of these sites, and planted trees often are not well adapted to high soil $\mathrm{pH}$, making $\mathrm{pH}$-induced mineral deficiencies common. Salt, both in the soil and in irrigation water, also is a problem, with soil electrical conductivities (EC) up to 140 common (an EC over 4 causes problems for many plants). Concentration of salts by evaporation from reservoirs can lead to salty irrigation water, increasing salt levels in the soil or directly damaging plant tissue.

Desert shrubs and grasses are the typical native vegetation in the dry valley locations described above, with native trees only found along some of the streams (and, of course, in the wetter and cooler mountains). Trees planted in these locations usually are not native and often are poorly adapted, leading to high maintenance needs and poor health. Though selection of better adapted trees and shrubs for the region is possible and will help, the lack of trees native to these sites will continue to make selection difficult.

Program factors. Programs and organizations also have had a great effect on urban/community forestry in the Intermountain West. In short, my survey results suggest a situation in the region in which agencies and nongovernmental organizations are having trouble keeping up with population growth and rapid development, especially due to limited funding, but where good programs and organizations exist that are slowly getting better.
Survey returns included 13 out of 14 state urban forestry coordinators, a $93 \%$ response rate for that group. Returns also included 2 of the regions' 4 volunteer coordinators, 1 utility forester, one city forester, 1 USFS State \& Private Forestry coordinator for R-4, and 3 Extension educators involved in U\&CF. Overall the respondents represent a group that should be well informed about the state of U\&CF in the region, though they would not be representative of all U\&CF practitioners in the region.

Respondents rated U\&CF in the Intermountain West as moderately strong or good, with a mean of 3.9 on a scale from 1 (weak or poor) to 6 (strong or good) (Figure 2). Strengths and weaknesses listed by respondents are shown in Table 1, with the numbers of responses in parentheses (responses were grouped, so 1 person could have more than 1 response in a particular group). Notable strengths involved state and local programs and cooperators, agency personnel, citizens, and educational programs. Corporations, arborists, and utility tree maintenance also were mentioned as strengths. The top weakness was inadequate funding and staff numbers, with 22 responses involving staff and/or money. Interestingly, a lack of community awareness, interest, and demand was cited as a weakness even though citizen awareness was listed by many as a strength. Outreach/ education and arborist quality also were listed as both strengths and weaknesses. This lack of consistency likely indicates variation in the region, because respondents were answering in relation to the situation in their particular area.

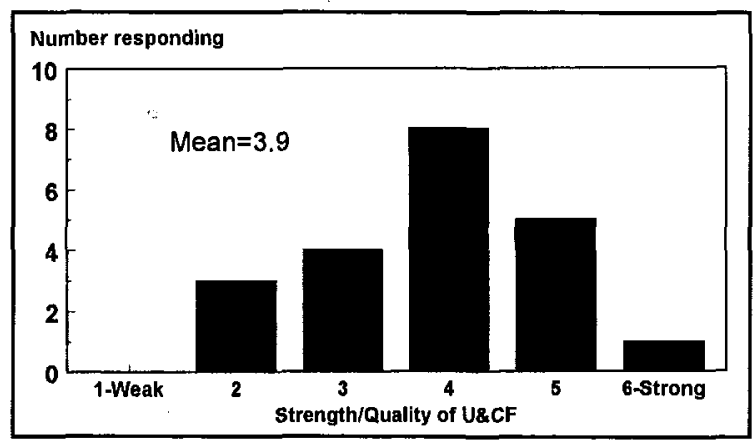

Figure 2. Respondents' ratings of the overall strength or quality of urban/community forestry in their area of the Intermountain West. 
Table 1. Summarization of strengths and weaknesses reported by respondents for U\&CF in their areas of the Intermountain West. Only responses occurring more than once are included, and numbers of responses are in parentheses. Responses were grouped, so 1 person could have more than 1 response in a particular group.

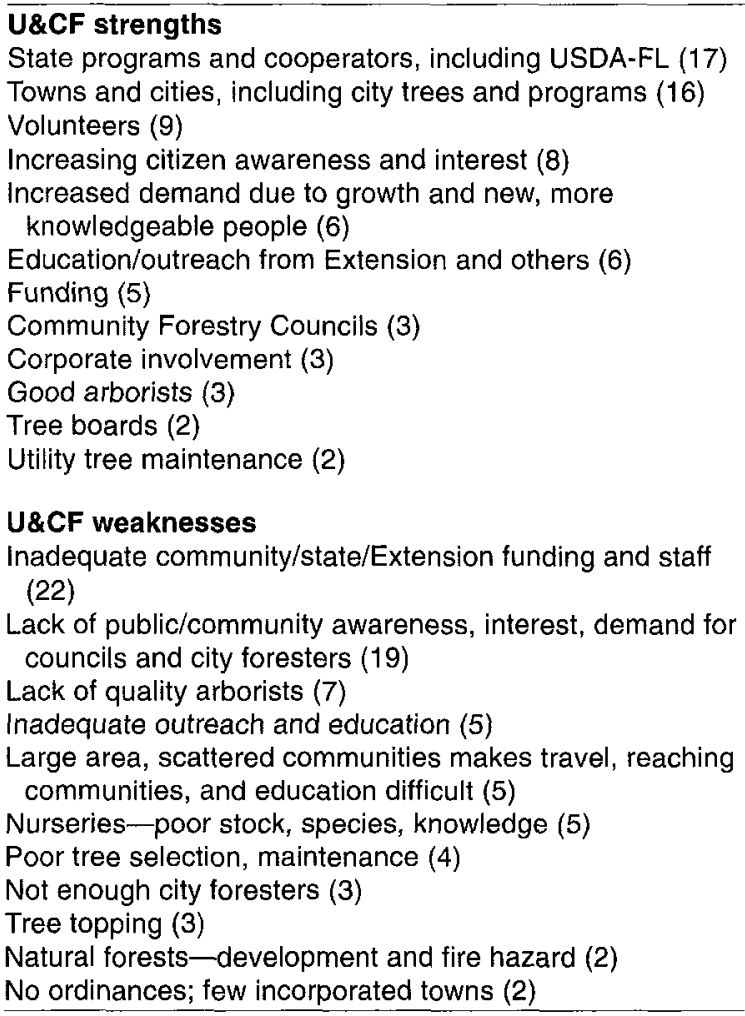

Many of these U\&CF strengths and weaknesses seem fairly universal and likely would be listed by people anywhere, though more populated regions would not have the weakness of having a large area with widely scattered communities. This scattering of population can make it difficult for state and regional agencies and organizations to adequately cover their area. Population growth may exaggerate this problem, because greater population means greater needs for personnel or programs, yet the communities in need are still just as scattered as ever. Population growth, however, was listed as an U\&CF strength rather than as a weakness.

When respondents were asked how they felt about the future of urban/community forestry in their area of the Intermountain West over the next 5 to 10 years, only 1 felt that it would get worse, while $5(24 \%)$ felt it would stay about the same and $15(71 \%)$ felt it would get better. Those that felt things would get better cited increased interest, awareness, demand, and education level of citizens and others involved with U\&CF, partially due to growth and changing demographics, as a primary reason for projected improvement. Other reasons given for improvement were the availability of better programs and education, more services to be offered by the state and cooperators, and better arborists. Though rapid population growth might be thought of as negative, respondents made it clear that they have hopes that growth will actually improve U\&CF in the Intermountain West. They believe that increased population and a strong economy will increase the funds available for government and nongovernment U\&CF programs, and that demographic changes may lead to better-educated citizens who appreciate quality landscapes and attractive communities and have the money to pay for them. Whether these positive changes will take place remains to be seen. Certainly average income levels in the region are increasing as low unemployment and a favorable business climate drive wages up.

Respondents listed the main difference between U\&CF in the Intermountain West and in other parts of the United States or the world as difficulty in growing trees due to climatic and site variables (19 responses). Also mentioned was difficulty in reaching the many small, widely separated communities with low populations (14), and lower demand and awareness of the need for community forestry, especially in rural communities (11). Minor differences receiving 2 or 3 responses included a sentiment for less government or distrust of government, urban growth into the wildland/urban interface, low funding due to the tax system or other reasons, a poorly developed tree care industry, and rapid population growth.

The top U\&CF research needs for the Intermountain West were listed as species adaptability for arid and high elevation climates (8 responses); environmental, economic, and social 
benefits of trees (8); how to develop and fund programs at the community level (6 responses); community forest health (5); planting and establishment of small versus large stock (5); and irrigation (3). Roots and soils, pruning, tree inventory, and urban/wildland interface management also were listed, with 2 responses each. Though many of these needs would be highly rated elsewhere, finding adaptable species is especially important for this region because of the lack of native trees and harsh sites as mentioned earlier. Growth of communities into nearby wildlands also offers some interesting challenges in terms of natural area and greenspace protection, protection of people and property from fire, and minimizing wildlife/people conflicts.

Respondents were asked to list people- and site-related problems in growing and caring for trees in the region. The top people-related problems were improper tree maintenance (17 responses); lack of education, awareness, and understanding of tree care (16); poor tree selection (15); improper planting (too deep, wire baskets; 12); improper pruning (topping; 13); improper irrigation (5); unprofessional or poor arborists (5); and construction damage (4). Top treeor site-related problems were soils (high $\mathrm{pH}$, salt, rocky, clay, compaction; 22 responses), water (too much or too little; 10), limited tree selection (6), temperature extremes (4), tree root damage (3), wind (3), and insects and diseases (2). Though no figures are available from other regions for comparison, most of the problems attributed to people and trees/sites appear universal to urban forests anywhere. However, some of the site-related problems may be more extreme in this region than in most other places. This underscores the importance of good landscape design and species and cultivar selection for this region.

Finally, respondents listed the most abundant tree species grown in urban/community forests in their area of the Intermountain West. Species mentioned at least 2 times were (response number in parentheses) Siberian elm (Ulmus pumila; 13), green ash (Fraxinus pennsylvanica; 12), cottonwood (Populus spp.; 10), Norway maple (Acer platanoides; 10), honeylocust (Gleditsia triacanthos; 7), boxelder (Acer negundo; 6),
Colorado blue spruce (Picea pungens; 6 ), Prunus spp. (6), silver maple (Acer saccharinum; 5), black locust (Robinia pseudoacacia; 3), linden (Tilia spp.; 3), London planetree (Platanus $\times$ acerifolia; 3), crabapple (Malus spp.; 2), and Russian-olive (Elaeagnus angustifolia; 2). Only boxelder and blue spruce are native to much of the region (several cottonwoods are native but are not commonly planted). Many of the remaining species are tough and tolerant of conditions in the region but are fairly undesirable in most cultivated landscapes, including Siberian elm, green ash (borer problems), silver maple (often severe iron chlorosis), black locust (borer problems), and Russian-olive (noxious weed in some locations).

Though many communities throughout the United States and the world have a preponderance of undesirable tree species, the list above reflects both the realities of the harsh climate and soil characteristics of the Intermountain West, along with the biases that residents of the region have from decades of planting these trees. Lack of knowledge and poor tree selection by citizens were mentioned previously as people-related problems in the region, and poor tree selection was mentioned as a major U\&CF weakness. Often residents favor the trees that were planted by previous generations, many of which were brought West without regard to their adaptability. Other more recent immigrants to the region want to recreate the landscapes they remember from the places they have lived previously. Again, many of these species end up being not well suited to Intermountain West conditions. Obviously, more research and better education are needed regarding tree selection and landscape design and maintenance in this region. Nurseries could help lead the way by offering more of the species and cultivars that are already being promoted by some tree advocates in the region.

\section{Conclusions}

The Intermountain West is a region not unlike many other regions in the United States in terms of U\&CF, with its share of strengths and weaknesses. However, its low population and fast rate of population growth stands out from most of the United States, with this growth offering both problems and 
opportunities for U\&CF. Harsh conditions and lack of native trees on most planting sites also make the Intermountain West fairly unique. Increased efforts to educate citizens and professionals, especially in tree selection and landscape design and maintenance, have the potential to greatly improve the region's community forests. Education and outreach efforts will be hindered, however, if funds and staffing for U\&CF programs at state and local levels do not keep pace with growth. Overall, it appears that improvement in the overall strength and quality of U\&CF in the Intermountain West is likely in the future.

\section{Literature Cited}

MedAccess Co. 1997. Statistical Abstract of the United States 1995. In Web page of MedAccess Corp., 420 Bedford Street Lexington, MA 02173 (http:// www.medaccess.com/census95/).

US Census Bureau. 1997a. Estimates of Housing Units, Households, Households by Age of Householder, and Persons per Household, ST-9620R. In Web page of the U.S. Census Bureau (http://www.census.gov/population/estimates/ housing/prhuhht $1 . t x t$ ).

US Census Bureau. 1997b. Map Stats. In Web page of the U.S. Census Bureau (http://www.census.gov/ datamap/www/index.html).

Acknowledgements. Support for this project came from Utah State University Cooperative Extension and the Utah Agricultural Experiment Station. Approved as journal paper no. 7015 .

Associate Professor

Department of Forest Resources

Utah State University

Logan, UT 84322-5215
Zusammenfassung. In diesem Artikel werden die Populationsfaktoren, Standortfaktoren und Programmfaktoren, die die urbane und kommunale Forstwirtschaft (U\&CF) in den westlichen Bergregionen der Bereinigten Staaten beeinflußen, aufgezählt, einschließlich der Informationen, die durch Forstexperten aus der Region in einer Umfrage gesammelt wurden. Die dabei hervortretenden Faktoren waren eine relativ geringe Bevölkerungsdichte, die in Städten und Kommunen über eine Große Fläche verteilt lebt, welche wiederum gerade jetzt einen starken Bevölkerungsanstieg erlebt, ein Mangel an natürlichen Baumvorkommen in den Tälern, wo die meisten Menschen leben, ungünstige Wachstumsbedingungen für Bäume, schlecht ausgestattete U\&CF-Programmen und ein Mangel an öffentlichem Bewußtsein für die Belange der Baumund Landschaftspflege. Der Region wird eine bessere Zukunft auf der Basis von Bevölkerungswachstum, demographischen Veränderungen, verstärktem öffentlichen Bewußtsein, verbesserter finanzieller Ausstattung der U\&CF-Programme und der Verfügbarkeit besser ausgebildeter Arboristen für die U\&CF vorausgesagt.

Resumen. Este reporte resume los factores gente/ población, los del sitio y los del programa, que influyen en una comunidad forestal y urbana (F\&U) en las Intermontañas del Oeste (Estados Unidos); incluyendo información recogida a través de una inspección de expertos F\&U en la región. Los principales factores que emergen incluyen una población relativamente baja viviendo en ciudades y pueblos, dispersos sobre una gran área, que está experimentando mayor crecimiento de la población; condiciones severas para el crecimiento de los árboles; programas F\&U pobremente fundados y dirigidos; y ausencia de conciencia comunal y ciudadana con relación a la selección de los árboles, diseño y cuidado del paisaje. Un mejoramiento futuro es predicho por F\&U en la región; basado en el crecimiento de la población, cambios demográficos, incremento de la conciencia y el interés ciudadano, fondos aumentados, organización de programas $\mathrm{F} \& \mathrm{U}$, y la disponibilidad de arboristas mejor entrenados. 